\title{
Impact of Utilitarian and Hedonic Attitudes on the Dimensions of Brand Trust
}

\author{
Yrd. Doç. Dr. Ceyda DENEÇLi \\ Prof. Dr. Nurhan BABÜR TOSUN
}

nişantaşı üniversitesi sanat ve tasarım fakültesi ceyda.denecli@nisantasi.edu.tr marmara üniversitesi iletişim fakültesi nurhan.tosun@marmara.edu.tr

\begin{abstract}
The brand trust that evolves from brand's ability to successfully deliver on its promises can be discussed in two dimensions: brand intention and brand reliability. The hedonic dimension, which is associated with certain emotions in customer's preference of a certain brand or the utilitarian dimension, which is associated with more rational aspects resulting from a product's ability to satisfy functional or physical roles can have an impact on the brand trust perceived by consumers. According to the results of the research it is found that the respondents with respect to utilitarian and hedonic dimension have a significant correlation with the reliability dimension of brand trust (for utilitarian dimension $r=0.62$, $p<0.01$; for the hedonic dimension $r=0.61, p<0.01$ ). And also utilitarian and hedonic dimension have a significant correlation with the intention dimension of brand trust (for hedonic dimension $r=0.55, p<0.01$; for utilitarian dimension $r=0.57, p<0.01)$. The results of this study indicate that the independent variables (hedonic and utilitarian attitudes) in the model have a significant impact on both the reliability and intention dimensions of the brand trust.
\end{abstract}

keywords: brand trust, branding, consumption, hedonic attitude, utilitarian attitude 


\section{Résumé}

\section{L'effet des attitudes utilitaires et hédoniques sur les dimensions de la confiance accordée aux marques}

La confiance envers une marque, qui évolue en fonction de la capacité d'une marque à tenir avec succès ses promesses peut être abordée en deux dimensions : l'intention (le but recherché) de la marque et la fiabilité de cette dernière. La dimension hédonique qui est liée à une certaine émotion du client dans la préférence qu'il a pour une marque donnée ou la dimension utilitaire, qui est associée à des aspects plus rationnels résultant de la capacité du produit à remplir un rôle fonctionnel ou physique, peuvent avoir une incidence sur la perception des consommateurs concernant la confiance qu'ils accordent à une marque. Dans ce contexte on a analysé l'effet des attitudes utilitaires et hédoniques sur l'achat des produits et des marques. Selon les résultats de la recherche, il est constaté que chez les répondants, la dimension utilitaire a une corrélation significative avec la dimension de fiabilité pour ce qui concerne "la confiance envers une marque " (pour la dimension hédonique, $r=0.62, p<0.01$; pour la dimension utilitaire, $r=0.61, p<0.01)$. Et par ailleurs les dimensions utilitaires et hédoniques ont également une corrélation significative avec la dimension du but recherché par une marque (pour la dimension hédonique, $r=0.55, p<0.01$; pour la dimension utilitaire, $r=0.57, p<0.01)$. Les résultats de cette étude indiquent que les variables indépendantes présentes dans le modèle, ont une incidence significative sur les deux dimensions relatives à " la confiance envers une marque " qui sont les dimensions de fiabilité et celle du but recherché par la marque.

mots-clés : confiance envers une marque, marquage, consommation, attitude hédonique, attitude utilitaire. 


\section{Özet}

\section{Hedonik ve Faydacı Tutumun Marka Güveni Boyutları Üzerindeki Rolü}

Markanın vaatlerini başarıı bir şekilde yerine getirmesi sonucu tüketicilerde oluşan marka güveni, marka niyeti ve marka güvenilirliliği olarak iki boyutta ele alınabilmektedir. Tüketicinin ürün ya da marka tercihlerinde belli duygularla ilişkili olan hedonik boyut ya da ürünün fonksiyonel ve fiziksel görevleri yerine getirmesinden ortaya çıkan daha rasyonel özelikler ile ilgili olan faydacı boyutun, tüketicilerin marka güveni üzerinde etkili olduğundan söz edilebilir. Bu bağlamda gerçekleştirilen araştırmada tüketicilerin ürünleri ya da markaları satın almalarına ilişkin hedonik ve faydacı tutumlarının marka güveni üzerinde etkili olup olmadığı incelenmiştir. Araştırmanın sonuçlarına göre güvenilirlik boyutu arasında katıımcıların faydacı ve hedonik boyuta ilişkin yaptıkları değerlendirmeler ile marka güveninin güvenilirlik boyutuyla arasında anlamlı bir ilişki (faydacı boyut için $r=0.62, p<0.01$; hedonic boyut için $r=0.61, p<0,01$ ) olduğu görülmektedir. Benzer şekilde katılımcıların faydacı ve hedonik boyuta ilişkin yaptıkları değerlendirmeler ile marka güveninin marka niyeti boyutuyla arasında anlamlı bir ilişki (faydacı boyut için $r=0,55, p<0,01$; hedonik boyut için $r=0.57, p<0.01$ ) bulunmaktadır. Araştırmanın sonuçları modeldeki bağımsız değişkenlerin (hedonik ve faydacı tutum) marka güveninin hem marka güvenilirliği hem de marka niyeti boyutları üzerinde anlamlı bir etkiye sahip olduğunu göstermektedir.

anahtar kelimeler: marka güveni, markalama, tüketim, hedonik tutum, faydacı tutum 


\section{Introduction}

The concept of trust has been examined in many studies from different perspectives, such as altruism (Frost et al. 1978; Hess, 1995), benevolence (Larzelere and Huston 1980: 596), honesty (Larzelere and Huston 1980; Hess 1995), dependability and fairness (Rempel et al. 1985: 96) and reliability (Doney and Cannon 1997; Morgan and Hunt 1994; Hess 1995). Based on the opinion that the considered dimensions are useful to cover different aspects of brand trust, the present study examines brand trust under two facets: brand reliability and brand intention. According to Delgado-Ballester (2004: 9-10), the brand reliability dimension is based on a brand's ability to successfully deliver on its promises, while brand intention is based on a brand's ability to prioritize the interests of consumers in case of problems with the use of the product, and involves issues such as altruism, benevolence, honesty, dependability and fairness

Consumers experience brands by establishing relations with them, similar to relations with people. Experiences with certain brands generate associations, thoughts and inferences about the brand. Consumers' experiences with brands are a highly influential source of brand trust (Delgado-Ballester and MunueraAlemán 2005: 188-189). Consumers' satisfaction with brands helps to minimize their perceptions of functional, financial, physical, social-psychological and time risks (Roselius 1971; Schiffman and Kanuk 1997; De Chernatony 2006; Quintal et al. 2010).

Consumers purchase products or brands that satisfy their performance criteria. Consumer expectations of products or brands based on the utilitarian dimension differ from those based on a hedonic approach (Chitturi et al. 2008: 50). Since consumers purchase products and brands based on these two basic dimensions (utilitarian and hedonic), consumer attitudes can be defined as twodimensional. Consumer preferences are influenced by the hedonic dimension, which is associated with certain emotions, or the utilitarian dimension, which is associated with more rational aspects resulting from a product's ability to satisfy functional or physical roles. In this sense, it can be argued that the utilitarian and hedonic attitudes may be influential on the customer's brand choice.

The present research will analyze the role of hedonic and utilitarian attitudes of consumers on brand trust. The remainder of the paper proceeds as follows: the next section provides a literature review, which is followed by an explanation of the data collection approaches and discussion of the findings. Implications for marketers and consumer buying decisions are then highlighted by identifying which one of the dimensions - hedonic or utilitarian - has the largest impact on brand reliability and brand intention, both of which are dimensions of brand trust, or whether both dimensions have an equal impact. The study specifically focuses on smartphone brands. 


\section{The concept of brand trust}

In today's increasingly competitive environment, brand managers are seeking methods for their brands by which to become the preferred choice of customers, by means of differentiating from their competitors in significant aspects (Shocker et al. 1994; Keller 2008; Doney and Cannon 1997; Esch et al. 2006). Companies try to build brand trust in order to gain competitive advantage (Ha 2004: 329) as brands are used to develop relationships with customers, which lead to trust (Lau and Lee 1999: 344). In other words, relations with brands mainly focus on trust. Hiscock (2001) claims that the main ingredient by which to create an intense bond between the consumer and the brand is trust.

In the literature, the concept of trust has been assigned different roles such as: an individual taking action based on the promises, ideas and actions of others which makes him/her confident in these others (McAllister 1995: 25); and the consumer's belief in the ability of a brand to satisfy the promised functions (Chaudhuri and Holbrook 2001: 81). Fukuyama (1995: 26) defined trust as: "the expectation that arises within a community of regular, honest, and cooperative behavior, based on commonly shared norms, on the part of other members of that community". These norms also include secular norms, such as professional standards and codes of conduct.

Moorman et al. (1993: 82) defined trust as the willingness of one party to believe in another party. This definition brings two general approaches to the concept of trust. The first approach takes trust as a belief and expectation of a party with respect to the honesty, specialty, reliability and good faith of the other, whereas the second approach views trust as behavioral intention or behavior reflecting belief in the other party, and involving vulnerability and uncertainty on the part of the trustor. As companies recognize that brand trust may have an impact on the target group, they use trust to reduce uncertainty when the target group feels vulnerable (Chaudhuri and Holbrook 2001: 82).

In indicating the concepts of trust and promise as basic determinants of branding success, Morgan and Hunt (1994), similar to Moorman et al. (1993), defined trust as the belief of one party in the reliability and integrity of another. However, Morgan and Hunt's definition differs from that of Moorman et al. (1993) with respect to behavioral intention in terms of "willingness to trust". According to Moorman et al. (1993), behavioral intention plays a significant role in the concept of trust. The reason for this is that if one of the parties finds the other party to be reliable, but lacks the willingness to trust the reliability of that party, the trust is limited. On the other hand, Morgan and Hunt state that "willingness" is unnecessary in definitions of trust and also state that the behavioural intention concept is an outcome of attitude (Morgan and Hunt 1994). 
The concept of brand trust under the framework of brand trust and intention (Delgado-Ballester 2004: 574) is based upon the trust-creating expectations that arise in consumers via their assessments of problems that may lead to risk. It may be argued that the antecedent of trust is "expected response". Accordingly, it is suggested that trust is formed as a result of the expectation that there will be some behaviors that will trigger responses. Similarly, with respect to the relationship developed with the brand, trust means accepting the brand's promises and believing that the brand will deliver on its promises (Champniss and Rodes Vila 2011: 169). In this context, it may be argued that the strength of the relationships between brands and individuals are shaped by the concept of trust.

Perception of brand trust as an expectation by consumers is related with subjects such prioritizing consumer interests over its own interests by the brand while conducting the liabilities and that the brand is technically sufficient. Therefore, it may be argued that brand trust reflects two distinct components. One of them is brand reliability, which means the ability of the brand to successfully deliver on its promises; the other is brand intention, which is based on the ability of the brand to prioritize the interests of consumers when unexpected problems arise with the consumption of the product (Delgado-Ballester 2004: 575).

\section{The concept of Hedonic and utilitarian consumption}

According to the predominant view in the literature, consumption may be considered as either "hedonic" or "utilitarian" (Batra and Ahtola 1990: 159; Dhar and Wertenbroh 2000: 60). Since consumers purchase goods and services for two basic reasons, consumer attitudes can be defined as two-dimensional. One of these dimensions relates to hedonic satisfaction, which is associated with emotional aspects, and the other relates to utilitarian satisfaction, which is associated with functional aspects, means and purposes that are not related to emotional aspects (Batra and Athola 1990: 159).

The root of hedonism dates back to ancient Greece. Developed in the 4th century BC, hedonism can be defined as a way of life which devotes to pleasure as the ultimate good... This pleasure, which may be defined as enjoyment or joy, was analyzed by Greek philosophers such as Aristippus, Socrates, and Epicurus. Although there are basic differences among these philosophers, it seems that there are many theories about the roles of happiness and pleasure (Odabaşı 1999; Wolfsdorf 2013). Separating the concepts of need and pleasure, Campbell (1987) defined the concept of pleasure in relation to certain images, fantasies, and dreams, and emphasized that the essential tendency in hedonist behaviors is to acquire pleasure and excitement. The hedonic structure of modern consumption is rooted in Western Europe, and England in particular, in the 18th Century. Academics interested in consumption and consumers suggest that modern consumers exhibit consumption behaviors that are not only rational and 
economic, but are also influenced by romantic emotions and motives (Odabaşı 1999: 112).

The utilitarian approach may be defined as the perception of use evolving from the ability of the product to satisfy its functional and physical aspects and duties. These functional and physical aspects form the product's functional value. Functional values play a significant role in terms of both product category and brand selection. On the other hand, hedonic meaning is associated with certain emotions. Music, art, and religious structures, as well as places visited, are associated with emotional value and hedonic meaning. Products and/ or services such as clothes, cosmetic materials, plastic surgery, health food and tattoos, all of which have an impact on an individual's own image, are also influential with respect to hedonic values (Arnould et al. 2004: 127-131). Utilitarian consumer behavior is a more rational behavioral attitude, and is akin to a duty. On the other hand, hedonic value is more subjective and personal. Hedonic consumption is more like an enjoyable experience, rather than the fulfilment of a duty (Babin et al. 1994: 646). While the consumption of many products involves both dimensions, consumers characterize certain products in fully hedonic terms, and others in fully utilitarian terms. The consumption of hedonic products is characterized by emotional and sensorial experiences, such as aesthetics, emotional pleasure, fantasy and entertainment (Hirschman and Holbrook 1982: 92; Dhar and Wertenbroch 2000: 61); consumption of utilitarian products is based on cognition, and meets beneficial, target-oriented, functional and practical functions (Dhar and Wertenbroch 2000: 61).

It may be argued that the basic objective of marketing is the reestablishment and reinforcement of bonds between the consumers and the brand. Consumers and their consumption behaviors may not be understood in terms of their behaviors, and usually cannot be explained logically. However, the important thing is to get closer to, and determine the wishes and needs of, consumers (Küçükerdoğan 2009: 82; Arnould et al. 2004). Consumers are motivated to satisfy their hedonic and utilitarian needs. While the satisfaction of utilitarian needs means that customers must place emphasis on objective and concrete qualities (such as the number of calories in food, the fuel a car consumes, etc.), hedonic needs are subjective and experiential. Consumers believe in products that satisfy needs such as excitement, trust, fantasy, etc. Consumers may also choose to buy products that provide both hedonic and utilitarian benefits. For instance, mink coats are soft and luxurious, while also being warm; in this case, mink coats address both hedonic and utilitarian consumption (Solomon 1994: 91).

\section{Relationship between brand trust and hedonic and utilitarian consumption}

The consumption phenomenon is a cultural and social process, in addition 
to being an economic process. While relating to humans' basic needs, the consumption phenomenon also plays an important role in people's determination and expression of their identities and social status in life.

The Puritan Ethic concept, which was beneficial to both society and the individual since it emphasized hard work, encouraged frugality and frowned on extravagance (Morgan 1967: 6-7). The weakening of this concept, along with ideological transformations, has extended the meaning of consumption to entail elements of success, pleasure, entertainment and freedom. People have started to view consumption as the essence of a good life, and the ability to consume more has become an indication of power and happiness. Lifestyle, which can be considered to have replaced class as the basis of social life, has been perceived as the essence of social identity. Especially with the economic prosperity seen during the years following the Second World War, the perceptions of consumption among people living in the USA and Western European countries, which turned into wealthy communities, included the importance of symbolic meanings of products, in addition to making general choices (Yanıklar 2006: 25). In the 1950s, discussions conducted by academics involved symbolic aspects of products. Levy (1959: 117) argued that people buy products not only for their functional aspects, but also for their symbolic meanings. In the 1960s, this lead to an overlap between consumers' lifestyles and the symbolic meanings of the products they purchase (Hirschman and Holbrook 1982: 92). In this context, it may be suggested that in addition to products with functional benefits, some products may also create positive emotions in consumers, resulting in increased consumption.

In the context of Western capitalism in the late 19th century, the consumption phenomenon was viewed not only as a utilitarianism and economic process, but also as a social and cultural process involving indicators and symbols. It was discovered that under the influence of social and cultural practices, in light of a modern consumption ideology, even if people do not have the economic power to buy the products they see in movies, via printed media, and on television, they still have the desire to own those products. In this sense, it can be said that consumption is not only related to needs, but is increasingly highly dependent on desires (Bocock 1993: 11-12).

Among the primary functions of the brand is its ability to reduce various risks for consumers. Via its image, promises, and the benefits perceived as being offered by it, the brand reduces the functional, financial, physical, social, psychological, and time risks for consumers, who trust the brand and feel that they thus do not have to take such risks (Tosun 2010: 15). Another way of maintaining the uniqueness of a brand is to ensure it comes equipped with emotional values that go beyond consumers' functional expectations (De Chernatony 2006: 40). 
Since brand trust is related to consumers' brand knowledge and experiences, consumers' direct contact with the brand in terms of trying and using the brand, or indirect contact via advertisements and word-of-mouth marketing, have a significant impact on brand trust (Krishnan 1996: 394). Consumers' experience and satisfaction with a brand is the most influential and valid source of brand trust (Ganesan 1994: 5).

It is clear that, in addition to functional benefits, emotional values also have a significant impact in relation to ensuring the differentiation of a brand from its competitors. Since trust in a brand is a priority for consumers when selecting a brand, it may be argued that both utilitarian and hedonic consumption is associated with brand trust.

Chaudhuri and Holbrook (2001) viewed hedonic and utilitarian values of products as the basic and determining factors of product category qualities. Hedonic value considers products in terms of their being enjoyable and pleasurable for consumers to use, whereas utilitarian value considers products in terms of the functions they satisfy in the consumers' daily lives.

The concepts of hedonic and utilitarian consumption may vary depending on a wide variety of factors such as the consumer, product consumed, socioeconomic conditions, qualities of the brand consumed, consumer expectations, perceptions, time, geography, and culture. All consumers may, from time to time, exhibit some hedonic, and some utilitarian, consumption behaviors.

\section{Research methodology}

The basic purpose of this research is to determine consumers' hedonic and utilitarian attitude dimensions with respect to smartphone brands, and to identify which dimension has a greater impact on brand trust. Smartphones have been selected as the product group in this study in order to investigate brand trust with respect to consumers' hedonic and utilitarian attitudes, since they represent a highly popular product group.

Samsung, Apple (iPhone), LG and Nokia brands were the four leading smartphone brands according to market share in 2013 (Reuters 2014), and thus were selected for analysis in this study. The purpose of the study is to examine the role of the consumers' hedonic and utilitarian consumption attitudes towards certain brands in relation to brand trust. In this context, the study intends to determine the hedonic and utilitarian attitudes of consumers in terms of the Samsung, iPhone, LG and Nokia smartphones, and the impact of these attitudes on perceptions of brand trust. 


\section{Hypotheses}

Based on studies related to brand trust and consumers' hedonic and utilitarian consumption values (Chaudhuri and Holbrook 2001; Delgado-Ballester 2004; Spangenberg et al. 1997; Chitturi et al. 2008), the following hypotheses are tested in this study:

H1: (a) utilitarian and (b) hedonic attitudes to a brand have an impact on the brand reliability dimension of brand trust.

$\mathrm{H} 2$ : (a) utilitarian and (b) hedonic attitudes to a brand have an impact on the brand intention dimension of brand trust.

\section{Data Collection}

In descriptive research, revealing the characteristics of a population or phenomena is being aimed (Gegez 2007: 41). This study was also realized by descriptive research model. The study tried to define the impacts of hedonic and utilitarian attitudes of consumers on brand trust and the relationships among the variables are examined.

The population of the study consists of Turkish consumers. It is stated that typical sample volume in "studies about problem solving" within the scope of marketing studies should be between 300 and 500 (Gegez 2007: 259). Therefore the research aims to obtain a minimum sample of 300 persons who are representative of Turkish consumers. A total of 335 people, obtained via convenience sampling, completed the survey form; however, after eliminating missing or erroneous survey forms following preliminary assessments, the number of valid surveys was 303.

The survey was conducted outside of four shopping malls in different neighborhoods on days when the shopping malls attract the highest number of visitors (Friday, Saturday and Sunday). Survey was conducted in two Shopping Malls with the greatest square meter space in the European side (Forum Istanbul $=175.000$ square meter and Mall of Istanbul $=148.840$ square meter) and two Shopping Malls with the greatest square meter space in the Anatolian side (Akasya Acıbadem $=80.000$ square meter and Maltepe Park $=75.000$ square meter). These Shopping Malls were selected among the Shopping Malls with the greatest square meter spaces according to Shopping Malls report acquired from Council of Shopping Centers- Turkey.

Of the respondents, $54 \%$ were women; $42 \%$ were aged 18 to $29,32 \%$ aged 30 to 39 , and the remaining $26 \%$ were aged 40 or over; $54 \%$ were graduates of undergraduate and post-graduate education; and $68 \%$ were of middle-income level (approximately 500 USD-2500 USD/month). 


\section{Measurement tool}

The survey forms were analyzed with the help of SPSS 20.0 for Windows software. In order to measure the respondents' brand trust, the scale developed by Garbarino and Johnson (1999); Hess (1995) and Morgan and Hunt (1994), and adapted by Delgado-Ballester (2004) was used. The scale includes a total of eight statements arranged according to a five-point Likert-type scale measuring two separate dimensions: reliability and intention. Each dimension includes four statements. A factor analysis with varimax rotation was conducted to confirm that the scale consists of two dimensions ( $K M O=0.95$; Bartlett's test $\mathrm{p}<0.05)$. A high value of $\mathrm{KMO}$ indicates that the sample size is adequate for factor analysis. Cronbach's alpha values calculated for the scale $(0.89$ for the dimension of brand reliability; 0.91 for the dimension of brand intention) indicate that the scale is quite reliable and has internal consistency (being above 0.80 (Field and Hole 2004)).

The study also used measures of utilitarian and hedonic consumer attitudes developed by Spangenberg et al. (1997) (based on the conceptual work of Hirschman and Holbrook (1982) and Batra and Athola (1991)). The adjectives included in this scale, which is originally semantic differential scale, were translated into statements and the scale was transformed into sevenpoint Likert-type scale. The original scale includes a total of 24 statements arranged according to a seven-point Likert-type scale measuring two separate dimensions: utilitarian and hedonic. However, it should be noted that in this study, the scale of the brand trust consists of five points. In this context, the data, which were originally measured in a seven-point Likert-type scale, were appropriately arranged in order to comply with the five-point scale format used in this work.

The factor analysis conducted for the scale confirms that the scale consists of two dimensions ( $\mathrm{KMO}=0.87$; Bartlett's test $\mathrm{p}<0.05)$. A high value of $\mathrm{KMO}$ indicates that the sample size is adequate for factor analysis. The Cronbach's alpha values calculated for the scale $(0.89$ for the utilitarian dimension; 0.89 for the hedonic dimension) indicate that the scale has internal consistency.

\section{Findings}

Initially, the research assessed the level of familiarity of the four brands selected. As a result of the preliminary assessment, the LG brand was not included in further study since the respondents were not familiar with it. The score for the LG brand was under 3 (of a five-point scale) whereas the other brands yielded a score of over 3 in terms familiarity. Accordingly, the role of familiarity with the brand was controlled with respect to the impact of consumers' perceptions of utilitarian and hedonic dimensions on brand trust. 
The responses obtained from the scales used in the research (Table 1) indicate that the respondents evaluated the brands somewhat positively with respect to both brand reliability (3.71/5.00) and brand intention and that they also evaluated them somewhat positively with respect to the utilitarian consumption dimension (3.51/5.00) and hedonic consumption dimension (3.32/5.00) against the brands.

Table 1: Average for variables and standard deviation and correlation analysis

\begin{tabular}{|l|l|l|l|l|l|l|}
\hline & $\mathrm{M}$ & $\mathrm{SD}$ & $(1)$ & $(2)$ & $(3)$ & (4) \\
\hline (1) Brand reliability & 3.71 & 1.16 & 1 & & & \\
\hline (2) Brand intention & 3.60 & 1.15 & $0.84^{* *}$ & 1 & & \\
\hline (3) Utilitarian & 3.51 & 1.38 & $0.62^{* *}$ & $0.55^{* *}$ & 1 & \\
\hline (4) Hedonic & 3.32 & 1.46 & $0.61^{* *}$ & $0.57^{* *}$ & 0.89 & 1 \\
\hline
\end{tabular}

${ }^{*} p<0.01,{ }^{*} p<0.05$

The results of the correlation analysis suggest that the evaluations made by the respondents with respect to the utilitarian and hedonic dimensions have a significant correlation with the reliability dimension of brand trust (for the utilitarian dimension $r=0.62, p<0.01$; for the hedonic dimension $r=0.61 p<0.01$ ). The correlation is positive and has a moderate correlation $(0.40<r<0.70)$. The Pearson correlation analysis ( $r$ ) is interpreted based on Guilford (1956). Accordingly, as the consumers' positive utilitarian and hedonic evaluations of the brand increase, their evaluations of the brand as reliable also increase. Similarly, the results suggest that the evaluations made by the respondents with respect to the utilitarian and hedonic dimension have a significant correlation with the brand intention dimension of brand trust (for the utilitarian dimension $r=0.55$, $p<0.01$; for the hedonic dimension $r=0.57 ; p<0.01$ ). The correlation is positive and has moderate a correlation $(0.40<r<0.70)$. Accordingly, as the consumers' positive utilitarian and hedonic evaluations increase, their evaluation of brand intention also increases.

In order to determine the impact of consumers' hedonic and utilitarian attitudes on the reliability dimension of brand trust, multiple regression analysis was used. Since brand trust has two distinct dimensions, the analysis was conducted for both, with the brand reliability dimension as the dependent variable and hedonic and utilitarian consumption as independent variables.

The regression analysis (Table 2 ), in which the dependent variable was the brand reliability dimension, generated a significant model $\left(R=0.64 R^{2}=0.41\right.$ $F=292.358 p=0.00<0.01$ ). The regression model obtained indicates that the independent variables in the model have significant impact on the reliability dimension of brand trust. The variables explain $41 \%$ of the changes in reliability 
dimension of brand trust $\left(R^{2}=0.41\right)$. The model analysis shows that both utilitarian and hedonic variables have significant impact on the reliability dimension of brand trust (thus supporting Hypothesis 1a Hypothesis 1b). Standard beta coefficients indicate that the utilitarian dimension has a greater impact on reliability compared to the hedonic dimension (Beta $=0.357$ and $B e t a=0.303$ respectively).

Table 2: Regression analysis results of the of hedonic and utilitarian dimension variables' impact on the brand reliability dimension of brand trust

\begin{tabular}{|l|l|l|l|l|l|}
\hline & B & Standard Error & Standard Beta & $T$ & $P$ \\
\hline (Constant) & 1.506 & 0.099 & & 15.282 & $0.000^{* *}$ \\
\hline Utilitarian & 0.346 & 0.051 & 0.357 & 6.744 & $0.000^{* *}$ \\
\hline Hedonic & 0.270 & 0.047 & 0.303 & 5.709 & $0.000^{* *}$ \\
\hline
\end{tabular}

$R=0.64, R^{2}=0.41, F=292.358, p=0.00<0.01$

${ }^{* *} p<0.01$

The regression analysis (Table 3 ) shows that considering brand intention as the dependent variable generated a significant model $\left(R=0.58 \quad R^{2}=0.34\right.$ $F=218.688 p=0.00<0.01)$. The regression model obtained indicates that the independent variables in the model have significant impact on the brand intention dimension of brand trust. The variables explain $34 \%$ of the changes in brand intention dimension of brand trust $\left(R^{2}=0.34\right)$. In addition, the model analysis shows that both utilitarian and hedonic variables have significant impact on the brand intention dimension of brand trust (thus supporting Hypothesis 2a and Hypothesis 2b). Standard beta coefficients indicate that the hedonic dimension has a greater impact on brand intention when compared to the utilitarian dimension (Beta $=0.373$ and Beta $=0.229$ respectively).

Table 3: Regression analysis results of hedonic and utilitarian dimension variables' impact on the brand intention dimension of brand trust

\begin{tabular}{|l|l|l|l|l|l|}
\hline & B & Standard Error & Standard Beta & $T$ & $P$ \\
\hline (Constant) & 1.661 & 0.103 & & 16.185 & $0.000^{* *}$ \\
\hline Utilitarian & 0.218 & 0.054 & 0.229 & 4.051 & $0.000^{* *}$ \\
\hline Hedonic & 0.328 & 0.050 & 0.373 & 6.613 & $0.000^{* *}$ \\
\hline
\end{tabular}

$R=0.58, R^{2}=0.34, F=218.688, p=0.00<0.01$

${ }^{* *} p<0.01$ 


\section{Conclusion}

In light of intense market competition, it may be argued that developing trustoriented cooperation with consumers may create advantages for corporations and brands that allow them to stand out in the competitive environment by means of differentiating from their competitors.

What is common with definitions of the concept of brand trust is that the brand, via the goods and services it offers, makes a promise to the target group, which expects to acquire value. The promise, which is one of the main components of the brand, tells consumers how good the quality of the product or the corporation will be. In this context, it can be said that the brand itself is an assurance, and a strong brand is representative of the trust placed in the promise, rather than the promise itself (Champniss and Rodes Vila 2011:165-166).

Brand trust may be viewed according to two dimensions: brand reliability, which arises when the brand successfully delivers on its promises and brand intention, which arises in case the brand prioritizes the interests of consumers when unexpected problems arise with respect to consumption of the product. While in the brand reliability dimension the trust is represented by a series of aspects and qualities based on technical functions and skills, in the brand intention dimension brand trust relates to an individual's emotional reliance on the brand.

Consumers' buying decision for products and brands based on two main motives indicate two dimensions: hedonic pleasure, which is based on emotional aspects and the utilitarian dimension, which is based on functional aspects and purposes that do not relate to emotional characteristics. Thus, it may be argued that the differentiation of a brand from other brands, and the brand's uniqueness, is related with associating that brand with emotional values, in addition to functional values.

The literature conducted suggests that little scholarly research has explicitly examined the impact of hedonic and utilitarian attitudes on brand trust. Therefore, the present study was conducted in the spirit of meeting this need.

The study reveals that the hedonic and utilitarian attitudes of consumers with respect to smartphones with which they are familiar have an impact on the brand reliability and brand intention dimensions of brand trust.

However, dimension-based analysis of the impact of the hedonic and utilitarian attitudes of consumers with respect to smartphones on brand trust indicates that the utilitarian dimension has a greater impact on the reliability dimension of brand trust compared to the hedonic dimension. Since the utilitarian dimension is related to characteristics and purposes that are independent of emotional characteristics and since it involves more rational behaviors, it may 
be suggested that the utilitarian dimension has a greater impact on the reliability dimension of brand trust, which represents more technical elements and skills compared to the hedonic dimension.

On the other hand, when the impact of consumers' hedonic and utilitarian attitudes towards smartphones on brand trust is analyzed based on brand intention, it seems that the hedonic dimension has a greater impact on brand intention when compared to the utilitarian dimension. This phenomenon can be explained by the fact that hedonic attitudes are more closely related to emotions than to rational behavior; likewise, the brand intention dimension expresses emotional reliance.

The main limitations of the study are: It was executed in Istanbul only and it focused only one product group (i.e. smart phones). Also the study has been carried out on people, who have been selected through convenience sampling. Therefore, the results of the study are valid only for the sample and cannot be generalized to whole population. It is recommend that any future studies on this subject analyze the role of hedonic and utilitarian attitudes of consumers on brand trust, with a focus on different product categories and different brands. In this way, the validity of the findings can be tested under different conditions. Furthermore, it is recommended that future research and studies include different variables such as consumers' brand loyalty and brand image, which will test whether the impact of consumers' hedonic and utilitarian attitudes on brand trust are affected by such variables. We believe that this study will shed light for more comprehensive studies with similar qualities stated above.

In order for marketing managers to ensure that their brands are more attractive compared to others and attract higher preference from consumers, they need to carry out activities that may help consumers develop both hedonic and utilitarian attitudes with respect to the brand. Given the findings of the present research, the development of only hedonic or only utilitarian attitudes will diminish the brand trust and therefore the probability of being preferred by consumers of the brand. Thus, marketing managers need to focus on activities that give due consideration to the correlation between brand trust dimensions and hedonic and utilitarian attitude.

\section{References}

Alışveriş Merkezleri ve Yatırımcıları Derneği 2015 Yılı Metrekare Büyüklüklerine Göre AVM Raporu, (2015).

ARNOULD Eric J., PRICE Linda \& ZINKHAN George M. (2004), Consumers, New York, McGrawHill. 
BABIN Barry. J., DARDEN William R. \& GRIFFIN Mitch (1994), "Measuring Hedonic and Utilitarian Shopping Value", Journal of Consumer Research, 20(4), pp. 644-656.

BATRA Rajeev \& AHTOLA Olli. T.i (1990), "Measuring the Hedonic and Utilitarian Sources of Consumer Attitudes", Marketing Letters, 2(2), pp. 159-170.

BOCOCK Robert (1997), Consumption, London, Routledge.

CAMPBELL Collin (1987), The Romantic Ethic and The Spirit of Modern Consumerism, Oxford, Blackwell Publishing.

CHAMPNISS Guy \& RODES VILA Fernando (2011), Brand Valued: How socially valued brands hold the key to a sustainable future and business success, United Kingdom, John Wiley \& Sons.

CHAUDHURI Arjun \& HOLBROOK Morris B. (2001), "The chain of effects from brand trust and brand affect to brand performance", Journal of Marketing, 65(2), pp. 81-93.

CHITTURI Ravindra, RAGHUNATHAN Rajagopal \& MAHAJAN Vijay (2008). "Delight by Design: The Role of Hedonic Versus Utilitarian Benefits", Journal of Marketing, pp. 48-63.

De CHERNATONY Leslie (2006), From Brand Vision to Brand Evaluation: The Strategic Process of Growing and Strengthening Brands, Oxford, Butfterworth Heinemann.

DELGADO-BALLESTER Elena \& MUNUERA-ALEMAN José Luis (2005), “Does brand trust matter to brand equity?", Journal of Product \& Brand Management, 14(3), pp. 187-196.

DELGADO-BALLESTER Elena (2004), "Applicability of a brand trust scale across product categories: A multigroup invariance analysis", European Journal of Marketing, 38(5), pp. 573-592.

DHAR Ravi \& WERTENBROCH Klaus (2000), "Consumer Choice Between Hedonic and Utilitarian Good", Journal of Marketing Research, XXXVII, pp. 60-71.

DONEY Patricia M. \& CANNON Joseph P. (1997), "An Examination of the Nature of Trust in Buyer-Seller Relationships", Journal of Marketing, 61(2), pp. 35-51.

ESCH Franz Rudolf, LANGNER Tobias, SCHMITT Bernd H. \& GEUS Patrick (2006), "Are brands forever? How brand knowledge and relationships affect current and future purchases", Journal of Product and Brand Management, 15(2), pp. 98-105.

FIELD Andy \& HOLE Graham J. (2004), How to Design and Report Experiments, London, Sage Publications.

FROST Taggart, STIMPSON David V., \& MAUGHAN Micol R. (1978), "Some correlates of trust", The Journal of Psychology, 99(1), pp.103-108. 
FUKUYAMA Francis (1995), Trust: The Social Virtues and the Creation of Prosperity, New York, Free Press.

GANESAN Shankar (1994), "Determinants of Long-Term Orientation in BuyerSeller Relationships", Journal of Marketing, 58(2), pp.1-19.

GARBARINO Ellen, \& JOHNSON, Mark S. (1999), "The Different Roles of Satisfaction, Trust, and Commitment in Customer Relationships", Journal of Marketing, 63(2), pp. 70-87.

GEGEZ Ahmet Ercan (2007), Pazar Araştırmaları, İstanbul, Beta Yayınevi.

GUILFORD Joy Paul (1956), Fundemental Statistics in Psychology and Education, New York, McGraw-Hill.

HA Hong-Youl (2004), "Factors influencing consumer perceptions of brand trust online", Journal of Product \& Brand Management, 13(5), pp. 329-342.

HESS Jeffrey S. (1995), "Construction and assessment of a scale to measure consumer trust", American Marketing Association, pp. 20-27.

HIRSCHMAN Elizabeth C. \& HOLBROOK Morris B. (1982), "Hedonic Consumption: Emerging Concepts, Methods and Propositions", Journal of Marketing, 46(3), pp. 92-101.

HISCOCK Jennifer (2001), Most Trusted Brands, Marketing, pp. 23-33. Available at: http://www. marketingmagazine.co.uk/article/56156/trusted-brands-winningtrust-consumers-key-lasting-brand-success-jennifer-hiscock-takes-look-uk-srespected-brands (accessed 21 December 2013).

KELLER Kevin Lane (2008), Strategic Brand Management: Building, Measuring, and Managing Brand Equity, New Jersey, Pearson International Edition.

KRISHNAN H.S. (1996), "Characteristics of memory associations: A consumerbased brand equity perspective", International Journal of Reseacrh in Marketing, 13(4), pp. 389-405.

KÜÇÜKERDOĞAN Rengin (2009), Reklam Nasıl Çözümlenir?, İstanbul, Beta Publishing.

LAU Geok Theng \& LEE Sook Han (1999), "Consumers' Trust in a Brand and the Link to Brand Loyalty", Journal of Market-Focused Management, 4(4), pp. 341-370.

LEVY Sidney J. (1959), "Symbols for Sale," Harvard Business Review, 37, pp. 117-124.

LARZELERE Robert E. \& HUSTON Ted L. (1980), "Toward Understanding Interpersonal Trust in Close Relationships", Journal of Marriage and Family, 42(3), pp. 595-604. 
McALLISTER Daniel J. (1995), "Affect and cognition based trust as foundations for interpersonal cooperation in organizations", Academy of Management Journal, 38(1), pp. 24-59.

MOORMAN Christine, DESHPANDE Rohit, \& ZALTMAN Gerald (1993), "Factors Affecting Trust in Market Research Relationships", Journal of Marketing, 57(1), pp. 81-101.

MORGAN Edmund S. (1967). "The Puritan Ethic and the American Revolution", The William and Mary Quarterly,. Vol. 24, No. 1, pp. 3-43.

MORGAN Robert M. \& HUNT Shelby D. (1994), "The Commitment-Trust Theory of Relationship Marketing", Journal of Marketing, 58(3), pp. 20-38.

ODABAȘI Yavuz (1999), Tüketim Kültürü, İstanbul, Sistem Publishing.

QUINTAL Vanessa Ann, LEE Julie Anne \& SOUTAR Geoffrey N. (2010), "Risk, Uncertainty and The Theory of Planned Behaviour: A Toursim Example", Tourism Management, 31 (6), pp. 797-805.

REMPEL John K., HOLMES, John G. \& ZANNA Mark P. (1985), "Trust in close relationships", Journal of Personality and Social Psychology, 49(1), pp. 95-112.

Reuters (2014), "Worldwide smartphone shipments top one billion units for the first time, according to IDC", available at: http://www.reuters.com/ article/2014/01/28/ma-idc-idUSnBw276506a+100+BSW20140128 (accessed 24 February 2014).

ROSELIUS Ted (1971), "Consumer Ranking of Risk Reduction Methods", Journal of Marketing, 35(1), pp. 56-61.

SCHIFFMAN Leon G. \& KANUK Leslie L. (1997), Consumer Behaviour, New Jersey, Prentice Hall.

SHOCKER Allan D., SRIVASTAVA Rajendra K. \& RUEKERT Robert W. (1994), "Challenges and Opportunities Facing Brand Management: An Introduction to the Special Issue", Journal of Marketing Research, 31(2), pp. 149-158.

SOLOMON Michael R. (1994), Consumer Behavior, Buying, Having and Being, Boston, Allyn and Bacon.

SPANGANBERG Eric R., VOSS Kevin E. \& CROWLEY Ayn E. (1997), "Measuring The Hedonic and Utilitarian Dimensions of Attitude: A Generally Applicable Scale", Advances in Consumer Research, 24, pp. 235-24.

TOSUN Nurhan Babür (2010), Iletişim Temelli Marka Yönetimi, İstanbul, Beta Publishing.

WOLFSDORF David (2013), Pleasure in Ancient Greek Philosophy, Cambridge, University Press.

YANIKLAR Cengiz (2006), Tüketimin Sosyolojisi, İstanbul, Birey Publishing. 